\title{
Urbane Tannese: Local Perspectives on Settlement Life in Port Vila
}

\section{Lamont Lindstrom}

\section{(2) OpenEdition \\ 1 Journals}

\section{Electronic version}

URL: https://journals.openedition.org/jso/6461

DOI: $10.4000 /$ jso.6461

ISSN: $1760-7256$

\section{Publisher}

Société des océanistes

\section{Printed version}

Date of publication: 15 December 2011

Number of pages: $255-266$

ISBN: 978-2-85430-037-4

ISSN: 0300-953x

\section{Electronic reference}

Lamont Lindstrom, "Urbane Tannese: Local Perspectives on Settlement Life in Port Vila", Journal de la Société des Océanistes [Online], 133 | 2e semestre 2011, Online since 31 December 2014, connection on 21 September 2021. URL: http://journals.openedition.org/jso/6461 ; DOI: https://doi.org/10.4000/ jso.6461

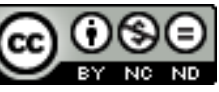

Journal de la société des océanistes est mis à disposition selon les termes de la Licence Creative Commons Attribution - Pas d'Utilisation Commerciale - Pas de Modification 4.0 International. 


\title{
Urbane Tannese: Local Perspectives on Settlement Life in Port Vila
}

by

\author{
Lamont LINDSTROM*
}

\begin{abstract}
Significant rural-urban migration has characterized the postcolonial Melanesian states including Vanuatu. Over the past 30 years, most people who once lived in Samaria village (Tanna Island) have moved to squatter settlements that ring Port Vila, Vanuatu's capital town. Life history interviewing of migrants now living in Port Vila's Blacksands and Ohlen neighbourhoods, and also of those remaining back on Tanna, document peoples' participation in urban migration, wage-labor, mobile telephony and other new media, religious organization, leadership and dispute settlement, and other aspects of urban life and how this participation is shaping a new urbanity in Vanuatu.
\end{abstract}

KEYwORDs: urban migration, urbanity, urban settlements, trans-island families

The year 1980 celebrated the transformation of colonial New Hebrides into independent Vanuatu. It also was a tipping point for urban migration within that new nation. Before 1980, Vanuatu's population migration patterns had been largely "circular". Bedford (1974), Bonnemaison (1976), Chapman (1978) and other geographers of colonial towns had described the predominant circular migration of Melanesian men (mostly) into town and then their return to home villages after limited periods of urban work and experience. Some, however, like Bonnemaison were already questioning this circular model,

\section{RÉSUMÉ}

L'histoire des États mélanésiens postcoloniaux, incluant le Vanuatu, fut notamment marquée par un puissant exode rural. Trente ans après l'indépendance de ce pays, la plupart des personnes originaires du village de Samaria (île de Tanna) vivent désormais dans les "bidonvilles" qui entourent la capitale Port-Vila sur l'île d'Efate. Le recueil des histoires de vie de ces migrants qui vivent aujourd'hui dans les quartiers de Blacksands et de Ohlen, mais également de celles des gens de Samaria restés dans leur village à Tanna, permet d'aborder les thèmes de la migration urbaine, du travail salarié, de la téléphonie mobile et d'autres nouveaux médias, de l'organisation religieuse, de l'autorité, du réglement des conflits et d'autres aspects de la vie à Port-Vila qui caractérisent les nouvelles formes d'identité urbaine à Vanuatu.

MOTS-CLÉS : migrations urbaines, urbanité, bidonvilles, familles trans-insulaires

finding that more-and-more islanders were heading into town to stay. In the 1980s, Haberkorn (1989) documented the transition from circular to "uncontrolled" or "one-way" migration among Port Vilass Paama and Pentecost Island communities. Haberkorn concluded that changing economic conditions, "formerly both necessitating and facilitating temporary rural-based circulation, have given way to a setting more conducive to long-term, or even permanent urban relocations" (1989: v; see also Lind, nd). He also documented increasing numbers of female migrants to town, beginning in the mid 1960s (1989: 151). 
My first period of fieldwork in what was then the New Hebrides took place in 1978 and 1979. I have returned, since those years, a half dozen times to visit friends living in and around Samaria village, located in the hills of southeast Tanna. Each time I return to Tanna, there are fewer people living in the village. Certainly, the post-1980 period also witnessed an efflorescence of new missions and religious ventures. Some people who have taken up these newer religious opportunities moved out to establish new hamlets in order to put distance between themselves and their still solidly Presbyterian relatives. But, in the main, Samaria since 1980 has emptied out gradually as young men and women hopped aboard interisland cargo ships to travel north to Port Vila.

These youth of 1980 are thus the first generation of Tannese urbanites. Whereas their fathers had been circular migrants, they instead became Bonnemaison's "uncontrolled" or Haberkorn's "long-term, permanent" urban residents. By the late 1970s, almost all Tannese men and some women had been off-island for limited periods. Many, in the 1940s, had worked for the American military on its Efate Island bases, recruited for periods of three months or longer to native labour corps. Some, after the war, had headed north again to work on Efate plantations and a few were employed cutting kauri (Agathis australis) on Aneityum. For most, though, these periods of work off-island were limited. Men eventually headed back home to marry, to raise children, and to maintain their family's place within the island's rich yet demanding network of exchange relationships.

Around 1980, people's migratory plans and choices changed. Young men and women headed to Vila and they stayed there, finding new sorts of work in and around town. They might return to Tanna to marry but then returned to town to raise their children there. In 1979, I surveyed residents of neighboring Samaria and Iankwanemwi hamlets. All men over 31 years of age had been off island at least once, and all but two out of twelve 16-30 year-old had done so. Only two of eleven women over 30 had been off-island, although five of 15 young women between 16 and 30 had been. In 2010, most of this younger generation, both men and women, have moved up to Port Vila or beyond. Samaria itself had a population of 48 in 1978 but only 15 in 2010 . Of 28 Samaria residents counted in 1978 who were still alive in 2010, 23 are living off-island. Whereas in the 1970s, husbands typically left wives back home in the village when they undertook limited periods of wage labour abroad, today entire families have relocated to Port Vila. One Samaria friend living in town, in fact, is de- plored by his relatives for having left his wife and most of his children to fend for themselves back home on the island.

I returned to Vanuatu in July-September 2010 to interview and record life histories of men and women who belong to a large extended family which originates in and around Samaria village. I digitally recorded the stories of thirteen migrants, men and women, who are living today in Port Vila's settlements and another seven life histories of people still living back home on Tanna. Interviews were recorded in southeast Tanna's Kwamera (Nife) language ${ }^{1}$ I draw on these life histories to explore individual experience of urban migration within post-colonial Vanuatu and migrant perspectives on urban, and village, life in these years since the nation's independence in 1980.

\section{The Settlements}

The passing of the Condominium opened new political, economical, and residential opportunities for Ni-Vanuatu. Back before the Pacific War, local people, unless they were employed "were not allowed to live in Vila for more than 15 days... All Ni-Vanuatu had to be out of town by nine in the evening unless they wished to have to report to the D.A. [District Agent] next day" (MacClancy, 1980: 95; see Mitchell, 2003: 360). Urban residential segregation eased after WW2 but most Tannese from Samaria who went up to Efate lived on or near plantations or other work sites (e.g., at Bellevue, Bukura plantation at Devils Point, the Abattoir) rather than in town. After 1980, however, Port Vila's surrounding settlements boomed. What had been coconut grove or empty bush rapidly transformed into Blacksands, Ohlen, Freswota and Freswin neighbourhoods. Siméoni (2009: 251) reports that the number of town migrants increased from 200 in 1955 to 3000 in 1967. In 1980, over $70 \%$ of Port Vila's residents were Melanesian (2009: 252). This percentage rose to $93 \%$ in 1993 (2009: 254); initial results from the 2009 census put Port Vila's population at 44,040 with men slightly outnumbering women (Vanuatu National Statistics Office, 2009: 3). The city's boundaries have expanded to include a fringe of new settlements and neighbourhoods that developed after 1980 (see Siméoni, 2009: 253). Over the years, people from Samaria have moved into several of these neighbourhoods, finding places to live in Manples, Blacksands, Freswota, and ESQAL (now Ohlen) Nabanga. Most live in Blacksands and Ohlen Nabanga where they have purchased or rent house sites from Ifira Island landowners. 
Port Vila's urban settlements, in the main, are shantytowns or "bidonvilles," as Siméoni notes:

"Ils sont un mélange de bidonvilles de d'habitations en dur, où la place du vivrier devient de plus en plus dérisoire. Là, la vie en groupe familial élargi perdure. Ce modèle d'organisation résidentielle domine le plus souvent par une nécessité socio-économique qui se traduit par l'achat d'une parcelle par un groupe d'individus et l'accueil des migrants de passage. " (2009: $254)^{2}$

Since 1980, city services have only gradually expanded into the settlements. Although most residents have tapped into the electric grid, they still obtain water from communal standpipes or urban wells and they make do with pit toilets (see Pacific Economic Cooperation Council, nd). Migrants throw together a variety of materials to construct housing: Corrugated sheet metal, commercial timber and local wood, plastic tarp, and cardboard. As Siméoni notes, extended families live together (having often pooled funds to purchase the house plot or to pay monthly rental fees) ${ }^{3}$, and household composition changes as some residents occasionally return home to visit family on Tanna and as new migrants come into town.
Relatives from the same village or island region often live in neighbouring houses but, over the years, settlements have come to house a mélange of migrants from throughout Vanuatu. Residential patterns reflect new interisland friendships and marital relations that have grown apace since the country's independence, and this increasingly complex mix of settlers in Port Vila's neighbourhoods perhaps inspires and echoes a strengthening national $\mathrm{Ni}$-Vanuatu identity. Nonetheless, migrants from Samaria, and from all of Vanuatu's rural communities, maintain deep and enduring ties with home villages, and they still organize and identify themselves according to these original villages and islands.

\section{Work}

Samaria's migrants are labour migrants. Since the Queensland and Fijian labour trade that began in the 1860s, people have left their island home seeking work abroad. After Queensland closed off its labour market in 1904, Tannese men and women continued to travel to plantation work sites throughout the New Hebrides and also down in New Caledonia. In the 1940s,

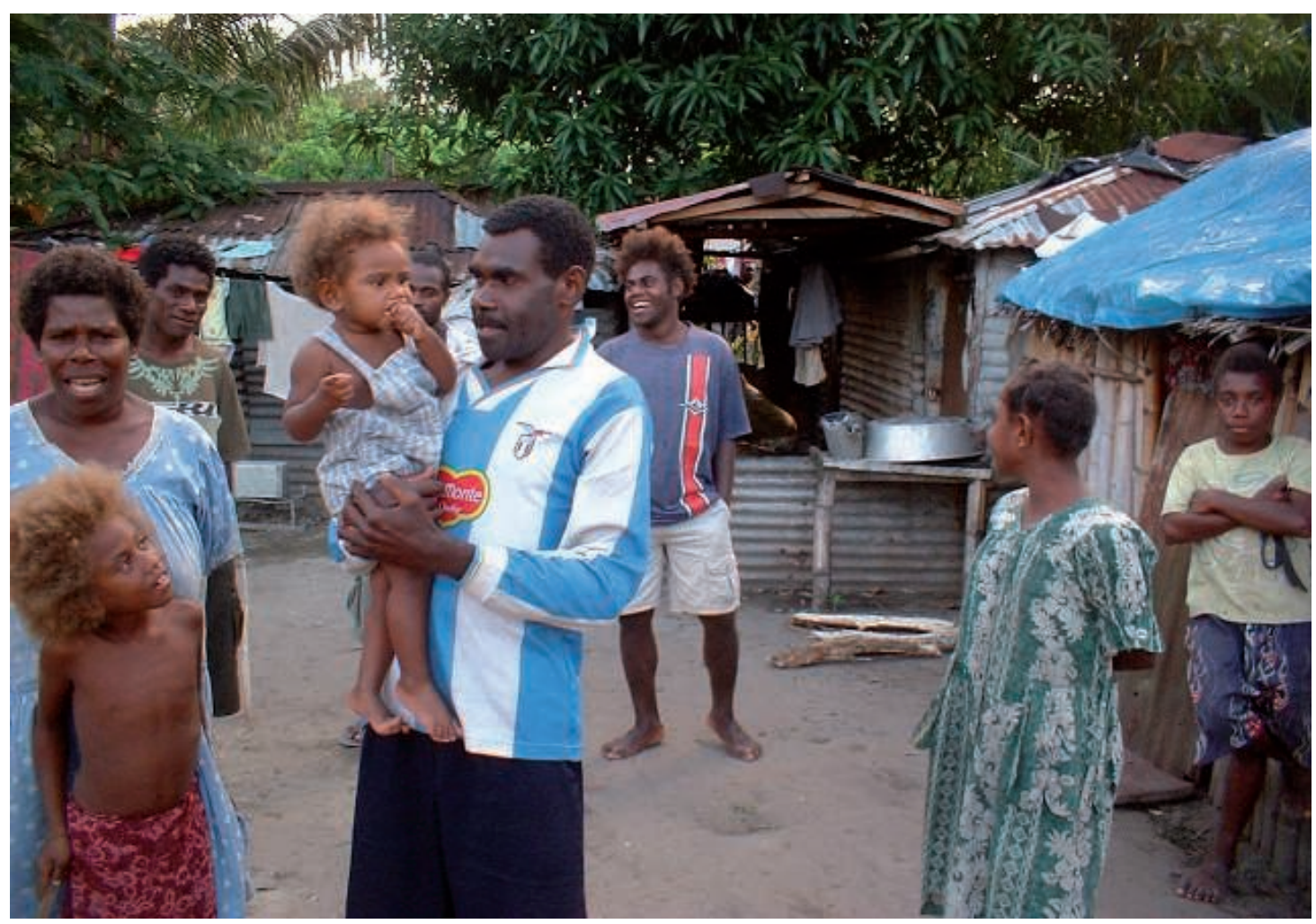

Рното 1. - Samaria Migrants in Blacksands (ㄷ Lindstrom)

2. See Mecartney (2000) for an excellent description of Blacksands' development into a permanent migrant settlement; see Sherkin (1999) for discussion of rural migrants from Mataso, and Keller (2009) for Futuna.

3. In Blacksands, Samaria families when they can pay 5000-10,000 vatu/month to their Ifira Island landlords. In Ohlen Nabanga and Freswin, people cite an original invitation from an Ifira politician to live free on this land in return for their votes. Land has since changed hands and they have been pressured to begin paying monthly rent but so far most have resisted. 
the Allied military recruited most of Tanna's men into native labour corps they put to work in and around Port Vila. Starting in the 1960s, greater educational options widened people's economic opportunities and some left work as plantation hand, stockman, or houseboy or girl to find employment in urban construction, commerce, and civil service.

Islanders continue to leave home seeking the chance to earn money. Mitchell, who worked with Blacksands youth, noted:

"From the beginning it was participation in wage work that gave Islanders the right to be in Port Vila. This idea that residency in Vila is linked to work is rooted in colonial experience, but it continues to inform contemporary life in town. » (2003: 360)

Villagers on Tanna remain subsistence farmers and economic life on the island proceeds without much cash. But need, and desire, for money have increased since 1980. People want money to pay for travel itself, for cloth and clothing, for garden tools, for occasional meals of imported food, recently for mobile telephones, and to pay fees the government demands of school children.

Migrants, when asked why they came to Vila, almost always cite this pressure to pay school fees for their children. Some of these children remain back in home villages to attend island schools, the fees for which migrant parents or older siblings pay with money earned up in Port Vila. Many migrants also bring their children along with them to town, knowing that the quality of urban schools is better than that of most rural institutions. Primary school fees range from 1000-5000 vatu/term, and secondary school fees, which typically include boarding costs, run from 20,000 to 25,000 vatu a term. In 2010, the government waived fees for primary education years 1 through 6 , but it continues to charge for secondary schooling. Back in Samaria, families in the late 1970s earned an average of 52,000 vatu/annum (with per capita earnings of approximately 12,000 vatu) (Lindstrom, 1981: 165). These earnings will have increased over the years but not remarkably insofar as copra and coffee cash cropping in Samaria has virtually disappeared since independence. Parents continue to struggle to find cash to pay secondary school fees and also to afford ancillary educational costs and other cash demands made by the elementary schools.

The young men who left Samaria for Vila in the 1970s and 1980s all did so, they say, in order to earn money to help pay for their younger siblings' education. Kamti's experience is typical:

"I wanted to go back to school myself, but my father said that my sister had passed [and been accepted to secondary school] but he had no way to pay school fees. I said, "okay, I'll quit school and go to Vila to earn money to pay her school fees"."

Like Kamti, many others would come to Vila to stay, working for money in order to pay for their own children's schooling, and also for their nieces and nephews back on Tanna. In the 1970s, young migrants sought plantation work at Bellevue, Tagabe, or Devils Point, cutting copra and tending cattle. Young women migrants took jobs as house-girls for European or Chinese families; and some came to town to take care of their working brothers' and sisters' children (see Rodman et al., 2007).

A decade later, young men began leaving plantation work in search of other sorts of employment in town. Some had earned enough money to purchase small cars or trucks they used as taxis in and around town, and some drove vehicles owned by others or provided by siblings who had found higher-paid employment after graduating from secondary school. By the 2000 s, migrant men next moved into the growing "security" field, working as guards in stores, banks and other establishments. In 2010, several continued to work security, at least part-time. Port Vila security firms often hire "contract" workers at daily rates to avoid paying government-mandated retirement, health, and other employee benefits. One friend, for example, works weekends, from dusk to dawn, guarding an ATM machine near a dance club. Another has a steadier, government job, providing night security for the Vanuatu Cultural Centre. And recently, beginning in 2008, Samaria's migrants have migrated overseas to work in New Zealand after that country instituted its "Recognised Seasonal Employer Scheme". In Hastings and other New Zealand farm communities, they pick apples and kiwi fruit saving their paychecks in hopes of purchasing taxis, paying university or trade school tuition, and the like back home. A few women have also been recruited to work in New Zealand. Other women work as seamstresses, cleaners, or clerks in town. Much of their work, too, is paid under the table as employers evade governmental regulation and mandated employee compensation, and some work long hours, six or even seven days a week, for Vanuatu's minimum wage $(26,000 \mathrm{vatu} / \mathrm{month})$ or less.

Those unemployed full or part-time in wage labour, as many women and youth are not, earn occasional cash through home businesses and other petty economic schemes. Settlement women make a little money taking on sewing projects, laundering, and preparing and selling cakes or other food. Some Samaria migrants have joined vaNwODS microcredit women's groups that plan and engage in various joint business enterprises. Other women, working on their own, act as loan-sharks, advancing small 


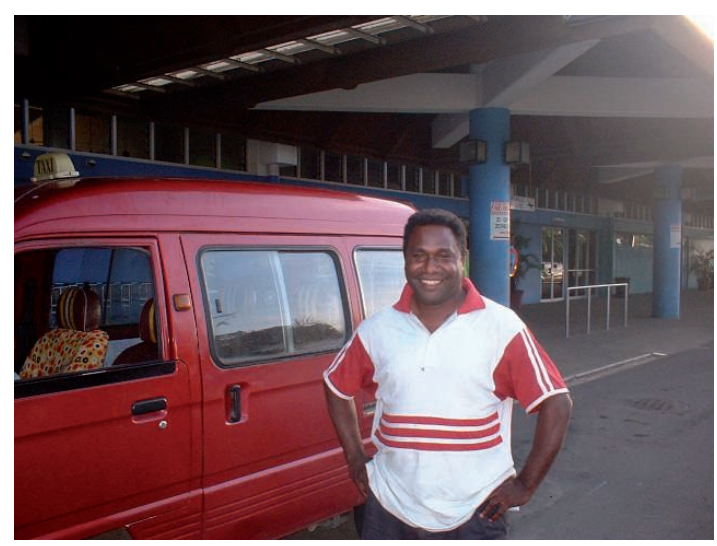

Рното 2. - Samaria Taxi Driver (CLindstrom)

sums of cash to people who find themselves caught in between fortnightly pay periods. And bingo is an increasingly popular and noisy settlement money-raiser. Dozens of women and men congregate around female bingo callers, buying into multiple bingo games in hopes of winning cash prizes or various sorts of merchandise (see Servy's paper in this issue). These petty businesses are important throughout the settlements in that steady wage-employment is difficult to obtain, especially for young school leaves (Mitchell, 2003). Many men and women remain unemployed or under-employed and are always on the lookout for opportunities to earn cash.

\section{Trans-Island Families}

Students of contemporary global population flows have remarked the emergence of transnational families and communities (e.g., Bryceson and Vuorela, 2002). This century, the Tannese have yet to travel so far. Unlike Samoans, Tongans, and north Pacific Islanders from the former U.S. Trust Territory of Micronesia, they have few opportunities to join more global migratory flows apart from recently established New Zealand and Australian guest worker programs and occasional employment on deep sea fishing vessels. They have, however, spread throughout Vanuatu and many are among the 3,000 or so $\mathrm{Ni}$-Vanuatu who live in and around Nouméa, New Caledonia.

Migrants have brought island ways into town, insofar as this is possible. Settlements reproduce the village. These divide up into multiple, smaller clusters of houses typically inhabited by extended family members, other people from the same original village or region, with occasional urban friends and affines from other islands. Samaria migrants living in Blacksands have named their neighbourhood after one of Tanna's volcanic vents. Settlements are composites of closely packed and overlapped hamlets and gar- dens. Virtually all settlement families have established small gardens and plantations near their houses, growing food to supplement what they can purchase with cash. They sometimes cook in earth ovens as they do Saturdays, back on Tanna, baking the taro, taro Fiji, manioc, bananas and other crops that they grow around their houses. People also fish and gather shellfish on Blacksands reefs. Samaria families in Blacksands, moreover, have cleared a circular kava-drinking ground near their housing cluster. Due to spatial limitations, they have located this very close to their houses, where it is less sheltered from view that it should be. But settlement men retire here to prepare and drink kava, when available, to settle community disputes, to conduct negotiations between families, and so forth just as stay-at-home relatives do back home on Tanna. Men gathered here to drink kava in 2010, for example, taking tamafa (a prayer punctuated by spitting out the last sip of a shell of kava) for the success of their sons running in a round-Efate island relay race the next day.

People have also imported into town existing exchange relationships with affines and kin, and they organize urban versions of circumcision, marriage, and funeral ceremonies among families. Since 1980, the figure of the taon jif (town chief) has emerged as urban community spokesman and go-to person when migrants fall into dispute among themselves or with settlers from other islands. This evolving urban chiefly authority has developed alongside and in association with leadership status back home in rural villages (Lindstrom, 1997). Migrants have also built, and support, many churches and religious organizations, including John Frum movement associations, which reflect and extend spiritual life from village to town; and settlements are full of "clevers" and seers who diagnose causes of disease or misfortune and combat sorcery attack. The very concatenation of settlement dwellers from different islands, and difficult economic challenges, no doubt heighten migrants' spiritual concerns and fears (see Rio, 2010).

In the 1970s, parental strategy aimed at keeping youth in the village or enticing them to return home after several months away in Vila. I often carried letters from Samaria parents to their wayward sons and daughters who had left home. These letters begged children to return, and parents exercised a number of strategies to bring them home. They ensured that teenaged sons planted gardens and built a first house in the village, and fathers would sometimes speed up marital negotiations hoping that the promise of a wife would entice a boy back home. Today, families continue to help young men to build their first houses in the village, and establish their first independent gardens. And migrants sometimes send money back to the village to 


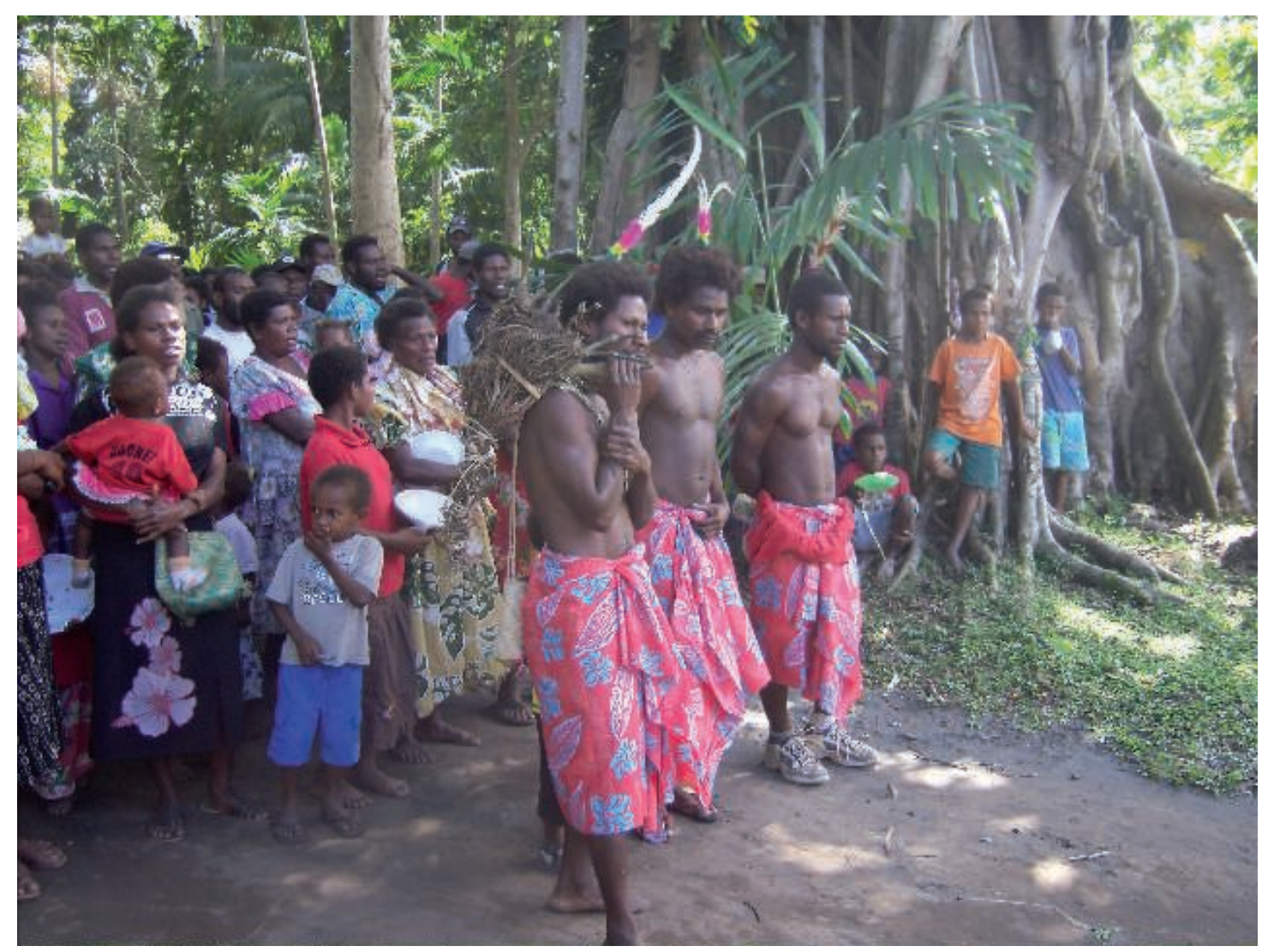

Рното 3. - John Mark’s First Shave Ceremony (@Lindstrom, August 2010, Tanna)

purchase cement brinks and sheet iron, slowly building more substantial houses that both stake their enduring residential and kinship claims and provide, one day, a place to live should they come home. Many of these houses, however, stand empty, used only occasionally when urbanites return for short village stays.

Thirty years later, entire families have moved to Port Vila and the challenge has shifted from enticing young migrants to come home to reinforcing ongoing relations among village and urban branches of trans-island families. Urbanites, when they can afford this, try to return home during the Christmas and New Year's holiday season. They sometimes send their children home to Tanna to be cared for by grandparents, aunts, or uncles. Village and urban relatives ship garden projects and store-bought goods (bolts of cloth, for example) to one another when they can as contributions to the family's exchange responsibilities, either in town or on Tanna.

Some Samaria families recently have elaborated, or at least revived, the customary ceremonial recognition of a boy's "first shave". Back in the 1970 s, parents rarely organized these exchanges. By 2010, however, increasing numbers of fathers are exchanging and preparing kava to be shared with their wife's family to mark ceremonially a son's first shave. A boy's mother's brother (or his cross-cousin) shaves off his first, fuzzy beard and will later drink kava and spit tamafa, praying for his nephew's successful life to come wherever the boy may in future go. Kin and friends in attendance line up to shake hands with the boy and his family, and they pile up gifts of store-bought goods such as sheets and towels, soap, basins, plates, and the like. Excited children gather around a generator and television to watch videos laid on for their entertainment. Such ritual recognition of a young man's approaching adulthood, and of his enduring familial connections and responsibilities, serves to strengthen youthful family ties. Most will soon move to Port Vila taking with them memories of this ceremonial marker of longterm economic ties and their duties to kin back home. Eriksen (2008: 69-73) has described the recent elaboration of another family exchange on Ambrym (between brothers and sisters) that also functions to maintain economic family relationships after the young women have migrated down to Port Vila.

Trans-island families which are dispersed today between village and urban settlements pool their resources, whenever possible, to meet joint exchange obligations which typically focus on marriages, the education of children, settling disputes, and funerals. These exchanges take place on Tanna, or up in Port Vila, depending on family circumstance. In the 1970s, expecta- 
tion was that urban migrants would send home a little money to help pay the school fees of their siblings, their own children, or their nieces and nephews. By 2010, however, people understand that urban life is far more expensive than is rural, and money often flows instead from island to town. I carried cash gifts up to Vila from several village mothers who were sending wads of vatu to adult children in town. Sometimes, villagers send instructions for family members to purchase certain goods and ship these down to Tanna. But sometimes they send money that they knew urban relatives need to pay rent or buy food. This sort of "reverse remittance" inverts the typical direction of 1970 s cash flows. And elsewhere in the Pacific, urban to rural remittances continue to characterize exchange relations among transnational families (see, e.g., Small 1997). It is notable that cash-poor Tanna villagers instead subvent their struggling urban kin. Iapwatu in Samaria, for example, expects and receives no money from his kin in Vila:

\section{"You saw that life in Vila is tough! It is bad! »}

Samaria migrants identify with home and most entertain plans to return one day to Tanna. Whereas a principal challenge for families in the 1970s and 1980s was to entice young, sometimes feckless migrants to return back home, today now that large numbers of people have moved to Vila, migrants are instead concerned to protect and maintain their rights back on the island, particularly their claims to village house sites and garden lands. The predicament today is to persuade a few people to remain back on Tanna, rather than to secure migrant returns from town. Current family strategy is to leave at least one or two family members back home who will protect the rights and claims of their urban kin should these be locally contested. Iapwatu, who watches over things back in Samaria, explained:

"I stay here to watch over our land. If someone tries to steal, and say that this land is his, I tell him "no it isn't". I am on duty, watching out for our land. If we all left home someone would steal our land. "

A second trans-island strategy involves child exchange and fosterage. Urban families may export a child or two back home to Tanna for short or more extended visits. One or two children often move in with village grandparents as household help. And these grandparents often shoulder the responsibility to organize circumcision and marriage feasts for their urban grandchildren, planting large gardens and raising pigs, which fathers living in town settlements would be harder pressed to meet.

Where people once kept in touch with letters and by exchanging the occasional photograph, the erection of cell towers in East Tanna in 2008 today allows much quicker communication among the members of trans-island families. Although Tanna's electric grid stops miles away from Samaria, villagers manage to recharge mobile phones with solar panels, diesel generators, or by sending them over to Lenakel (Blakman Taon) stores where they pay shopkeepers 50 vatu for a recharge. Telephone calls are increasingly important in tying trans-island families together. Although people are frequently short of cash, and telephone minutes, they can freely send the text message "Please Call Me" when they need to connect.

\section{Urbanity}

The youth of 1980 are today the first generation of permanent, or semi-permanent, migrants residing in Port Vila settlements (see Goddard, 2005, 2010 for a comparable analysis of rural migration and urbanity in Papua New Guinea's capital city, Port Moresby). They have found occasional work, made lives, and raised their children in town. Although trans-island families remain tied to rural roots, migrants because of their extended experience in town have achieved a certain urbanity. Claims to at least some urban poise and sophistication, however, are common as most adults have at passing experience of settlement life. A rural/ urban cultural divide among the community does not much exist given regular flows from island to town and town to island. Everyone is better acquainted with town life and practices than were parents of the 1960s and 1970s.

Settlement life, although burdened with economic difficulty, sometime tense relations with neighbours, and nostalgia for home, features regular activities and excitements. People therefore question one another's motives for moving to Port Vila and staying there. Yes, everyone needs cash to pay school fees but this is also a handy and socially acceptable excuse. One's actual motivation to migrate, some suspect, is to trade dull village life for the city's brighter lights. Electricity, stores, civic events, television broadcasts, and Port Vila's system of minibuses and taxis make life easier and more vibrant than what the island scene typically offers, at least for people with vatu in their pockets.

Although Blacksands and Ohlen residents live on the outskirts of Port Vila, they regularly come into town to work, shop, or kill time. Mitchell describes settlement youth who hungrily "consume images" and thereby tap into global cultural flows carried by television, movies, DVDs, and CDs (2003: 370-371; see also Rawlings, 1999). Settlement dwellers, especially underemployed youth, have frequent opportunities 
to observe and interact with Port Vila's growing numbers of international tourists, and they "eye shop" (Mitchell, 2003: 373) around town, checking out tourist behavior in urban venues such as streets, resorts, and nightclubs and studying the window displays of duty-free and other stores that cater to an international clientele. These opportunities to observe visitors from abroad and, occasionally, to consume imported goods, bring global imagery and products into the heart of the settlements. As Mitchell observed,

« eye-shopping places young people in the world of commodities and desire. " (2003: 373)

Even before Vanuatu's tourist boom, urbanites managed to tap into global cultural flows. Local musicians were deeply influenced by reggae styles of the 1970s, and these remain popular although augmented today by rap, heavy metal, and other world musical genres (see Weiss, 2009 for discussion of parallel global influences in urban Tanzania). Young men and women constantly adopt new dress and hair styles that surge through settlements from braiding to twisting, to corn rows, to sagging jeans, and there is ongoing public debate over the propriety of local women wearing the trousers or, worse, the shorts they see sported by tourists (Cummings, 2008). Glenda complained that Vila today is Babylon:
«You see a woman but don't know she is a woman until she turns towards you and you see her breasts. They were all sorts of clothing. They've borrowed foreign styles. "

The more religiously inclined dress instead in ties, long trousers, and white shirts and they copy incoming global evangelical Christian practices including speaking in tongues, altar calls, and the laying on of healing hands. The Internet, too, now furnishes relentless images and information which people use to acquire and display their urbanity. Migrants have brought computers into the settlements although these may not yet there have Internet access. They come in handy, though, when making copies of DVDs and CDs, and young migrants may go online at various Internet cafes and wif hotspots in town. Digicel and TVL Smile mobile phones also link settlers into the world beyond Vanuatu. People find the money, occasionally, to call family members living abroad in New Caledonia and also guest-working in New Zealand. The Bislama term mobael now claims a doubled implication with urbanity. It was used first, after independence, to refer to Vanuatu's Mobile Police Force. Many settlement youth are both fascinated by and apprehensive of these representatives of state authority. Although the mobael and the regular police have met settlement violence with

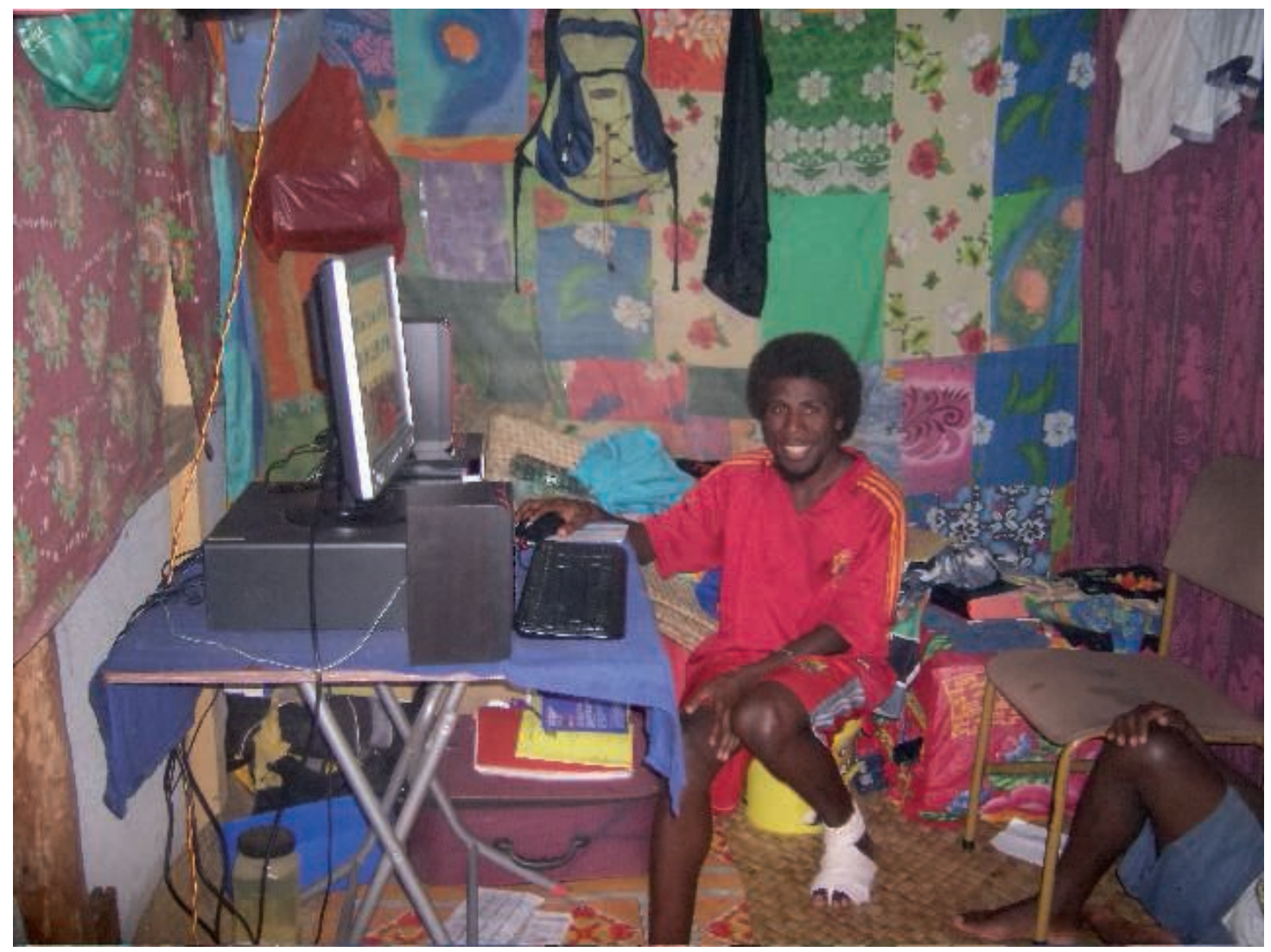

Рното 4. - Efrem at his Computer, Ohlen Nabanga (@Lindstrom) 
their own violence (see Mitchell, 2000; 2011: 40), their snappy uniforms, and especially their heavy black boots, captivate many boys and young men. The mobael police epitomize urbanity and modern style, and desire for black boots in particular has spread widely throughout the settlements. And, recently, the term mobael has surfaced again with mobile telephones. These, too, symbolize global, modern urbanity and the large majority of Ni-Vanuatu, both urban and rural, have hurried to purchase one ${ }^{4}$. The 2009 census counted $76 \%$ of the population which already had acquired phones and this figure today is certainly higher (Vanuatu National Statistics Office, 2009: 27). This modern "mobility," as a marker of urbanity and global connection, no doubt reflects an older, traditional appreciation of the personal advantages of travel and movement within island prestige systems (see Bonnemaison, 1979).

\section{Urban Discontent and Village Nostalgia}

Like the mobael police, the mobael telephone also threatens danger which lurks beneath its attractions. The police, although stylish, are feared for beating and unjustly detaining settlement suspects. And those telephones, too, despite their convenience and their intimation of the urbane, can also kill. Mysterious night callers take control of the minds and bodies of hapless victims who make the mistake of answering a midnight ring. And these strange calls and peculiar text messages are very commonly received. People blame the krangki network, but perhaps darker forces are at work? Mobiles, although urbane, may bring violence, even death. Those useful phones which allow trans-island families to keep in touch also carry more dangerous, even deadly, messages.

This sort of urban nervousness is widespread in settlements throughout the post-colonial world. All sorts of new sorcery fears have multiplied as rural migrants deal with the economic and everyday challenges of urban life (see Geschiere, 1997). In Vanuatu, too, there is a constant, underlying fear of nakaemas or poesin - sorcery - that cuts through Port Vila's settlements. Settlements in recent years have filled with gossip about secret vampires who suck the blood of the unwary, or about child-killing mothers, rapes and mysterious deaths (Rio, 2010; 2011). Disputes over suspected sorcery have escalated into violent confrontation, as happened in 2009 when migrants from Tanna and Ambrym battled one another, burning down a number of houses in Blacksands. Sorcery suspicions provide explanations for illness, madness, and other misfortune. And urban illness and misfortune are all too ordinary and widespread given the economic hardships and uncertainties that shadow life in Ohlen and Blacksands.

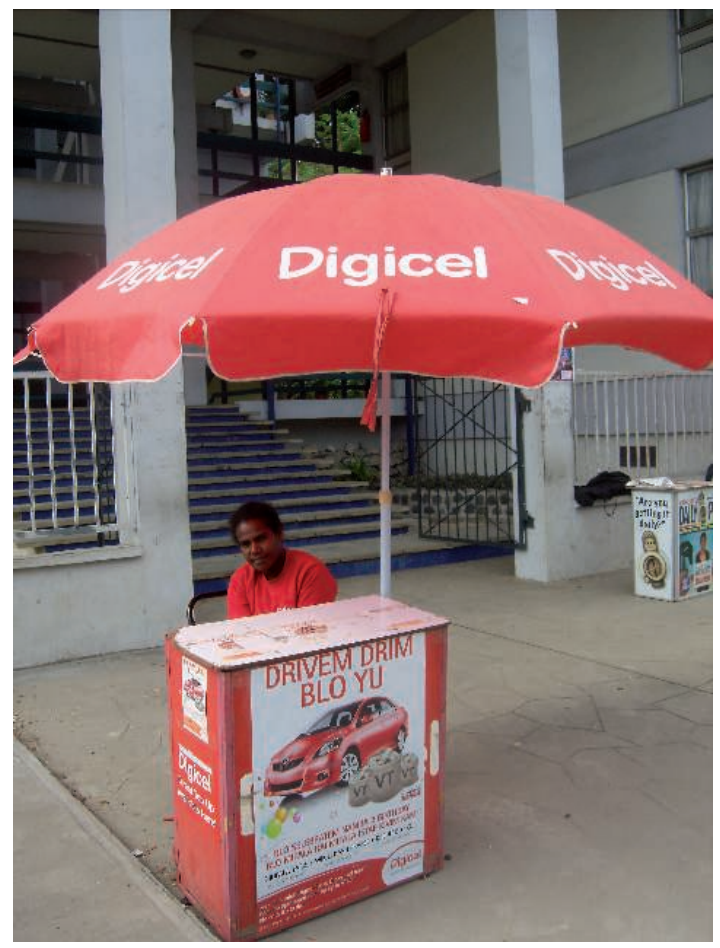

Рното 5. - Digicel mobael (C) Lindstrom, Port Vila)

It is perhaps no surprise that urban migrants, since the 1980s, have readily adopted the Bislama term sekiuriti (and also wajman and gadman). Samarias migrant men took up new employment opportunities, working as increasingly ubiquitous security guards, just as people were more-and-more anxious about the real and supernatural dangers of settlement life. Sekiuriti is an increasingly common concern both among Port Vila's expatriate shopkeepers and among settlement residents fearful of neighbours who may be up to no good. Older migrants are also critical of increased youthful use of marijuana, and they point out lazybone layabouts who grow, smoke, and sell the drug throughout the settlements. Marijuana enthusiasts have brought the plant back to Tanna and smoke it there too, but many parents are convinced that its use leads to irresponsibility and madness.

Most migrants express these sorts of critical and jaundiced views of settlement life. Only one Samaria migrant, one of the earliest to leave Tanna who lives today in Freswota 4, had much good 
to say about his urban community. Everyone else complained about life in town, comparing this with the idyllic village back home (although Glenda and several other women noted with approval that their husbands in town often do more cooking, washing up, and childcare than they would back on Tanna). Migrants phrase their complaints in economic terms. In Vila, money rules. On Tanna, everything is free and real "love" prevails. In town, rude commerce has overtaken the friendlier sorts of reciprocal exchange that pertain in the village. Antoine complained,

"Life in Vila is a bit difficult. Everything involves money. You eat money. You sleep money. On Tanna, there's no money. Everything is free. I think money is bad. But back home, life is good. "

Such complaint is common across Melanesia as urban migrants are pulled into cash economies and wage labour (see Lind, nd). Some suspect that pecuniary relations so dominate modern life that White parents charge their own small children for room and board.

In addition to sorcery peril and cruel demand for cash, migrants worry that their urban children have been cast adrift from their island roots. Some, especially those born to parents from different islands, do not learn well local languages. Back on Tanna, children first learn their mothers' and fathers' languages and they pick up Bislama later when they attend local pre-schools and elementary schools. Samaria migrants in Vila, however, often use Bislama with their babies and young children and, although all the older children in Blacksands and Ohlen I met had indeed learned Nife (Southeast Tanna) language, my impression is that many of these did so only after first learning Bislama. The progression of language learning in town is reversed, compared with village practice. Iau, for example, said,

" My two grandchildren speak Bislama, but if you talk to them in our language they understand, although they mix in the language of White people. "

Parents, and young people themselves, often complain of lack of opportunity to learn kastom in general, by which they typically mean local stories, songs and dance styles, family histories, and genealogy.

Romantic memories of village life parallel condemnations of Port Vila's difficult and sometimes dangerous settlements and the rule of money. Village kava is better. Life is easier. People are more humane. Samaria migrants even bragged, wrongly, that their kin back home had flattered out the trail up to the village transforming this into an easy stroll. Such island nostalgia is common even among youth who have spent little, or no, time back home. On Tanna, people are skeptical of such romances, figuring that if their migrant kin really did one day return home the everyday hardships of village life would soon rouse them to run back to town. Still, fond memories of the good village, where everything is free and where love prevails, establish the broader context for people's critical assessments of settlement life.

\section{Imagined Returns}

Nostalgia for the village also shapes people's imagination of their futures. All migrants I interviewed insisted that they would, one day, return home. Glenda is typical:

" I am tired of this place! I want to go back home. »

But such hopeful returns often happen only after death. Extended families sometimes pool money to fly the corpses of their relatives for burial back home. Migrants, however, hope to retire to Tanna while they are still breathing. They assert that they will, one day, return back to Samaria but they plan to leave most of the children working in Vila. This will allow them continued visits back and forth between town and village.

Physical presence is an important component of everyday social relationships on Tanna. Being there for people, whether this involves attending dispute-settlement meetings, joining gardening or house-building work groups, meeting to drink kava together, or unplanned daily shared interaction in general, symbolizes the depth of one's connections. Absence, conversely, signals social distance, detachment, and even hostility. Migrants, therefore, are concerned to nourish their relations with kin back home by whatever means possible. Mobile telephones, certainly, have recently facilitated many families' transisland identities and their efforts to cultivate relationships with folks back home. A migrant friend Taimweren, for example, received a call the same day his wife's father passed away down on Tanna. He hurried to scrape together enough money from friends and kin to fly her back home for the funeral. Another settler regularly calls his mother in Samaria to check on her health.

At issue within all migrant communities are identity claims and homeland ties of children born and raised abroad. In Port Vila settlements, many young people have had only passing connection with their parents' home village and with kinfolk resident there. More and more urban children are "mixed" with mothers and fathers from different islands and regions. This further complicates trans-island family relations. Will these urban youth continue to identify as 
Man Samaria, or even Man Tanna? Or will they increasingly claim newer Man Blacksands and Man Ohlen Nabanga identities that overshadow parental island roots? Village homes continue to offer sanctuary to which people may withdraw when urban life becomes economically and politically too difficult (although people back in Samaria say that they would be hardpressed to welcome everyone home should they all leave Vila en masse) $)^{5}$. And ongoing friction among migrants from this or that island within the settlements helps maintain original identities as people clump together for support and protection. Still, as with migrant communities anywhere, tensions between past and present relationships and responsibilities must increase as years go by.

Urban migrants in Port Vila today comprise the first generation of permanent, "one-way" newcomers to Port Vila. Villagers from Samaria who migrated to town in the 1970s and 1980s are now between 40 and 60 years of age. Although all look forward to returning home to Tanna, it remains to be seen if they will indeed do so after they retire from wage labour, as once did their more "circular migrant" parents and grandparents. In Freswin settlement, Soarum's imagined future is typical:

"My plan is perhaps not to die here. But of course if I get sick, or if God takes away my breath, it is here that I will stop breathing. But my plan is to return home. As soon as I finish paying school fees for my two sons, I am going back home to die on Tanna. "

\section{Acknowledgments}

I thank the Wenner-Gren Foundation for Anthropological Research and the University of Bergen Department of Social Anthropology's Pacific Alternatives Project for supporting field research in Vanuatu in 2010. I also thank Joel Iau, Harry Iapwatu, and other good Samaritans for offering friendship and helpful conversation, as always. I presented an initial version of this paper in an October 2010 seminar, "Urban life and articulation of modernity in the Pacific", organized by Knut Rio, Annelin Eriksen, Edvard Hviding and other members of the Dept. of Social Anthropology, University of Bergen; I thank fellow participants for useful comments.

\section{BIBLIOGRAPHY}

Bedford Ronald D., 1974. Models and Migration in a Melanesian Archipelago, New Zealand Geographer 30, pp. 129-150.

Bonnemaison Joël, 1976. Circular Migration and Uncontrolled Migration in the New Hebrides, South Pacific Bulletin 26 (4), pp. 7-12.

—, 1979. Les voyages et l'enracinement : formes de fixation et de mobilité dans les sociétés traditionnelles des Nouvelles-Hébrides, L'Espace géographique 8, pp. 303-318.

Bryceson Deborah and Ulla Vuorela (eds), 2002. The Transnational Family: New European Frontiers and Global Networks, Oxford, Berg.

Chapman Murray, 1978. On the Cross-cultural Study of Circulation, International Migration Review 12, pp. 559-569.

Cummings Maggie, 2008. The Trouble with Trousers: Gossip, Kastom, and Sexual Culture in Vanuatu, in Leslie Butt and Richard Eves (eds), Making Sense of Aids: Culture, Sexuality, and Power in Melanesia, Honolulu, University of Hawaii Press, pp. 133-149.

Eriksen Annelin, 2008. Gender, Christianity and Change in Vanuatu: An Analysis of Social Movements in North Ambrym, Aldershot, Ashgate.

Geschiere Peter, 1997. The Modernity of Witchcraft: Politics and the Occult in Postcolonial Africa, Charlottesville, University of Virginia Press.

Goddard Michael, 2005. Unseen City: Anthropological Perspectives on Port Moresby, Papua New Guinea, Honolulu, University of Hawaii Press.

—, 2010. Villagers And the City: Melanesian Experiences of Port Moresby, Papua New Guinea, Oxford, Sean Kingston Publishing.

Haberkorn Gerald, 1989. Port Vila: Transit Station or Final Stop? Recent Developments in Ni-Vanuatu Population Mobility, Canberra, National Centre for Development Studies, Research School of Pacific Studies, Australian National University.

Keller Janet Dixon, 2009. Geographies of Memory and Identity in Oceaniam, in D. Fairchild Ruggles and Helaine Silverman (eds), Intangible Heritage Embodied, Dordrecht, Springer, pp. 127-136. 
Lind Craig, nd. Why the Future is Selfish and Could Kill: Imagining One's Place in the Future through Choices Concerning Female Contraception, unpublished paper.

Lindstrom Lamont, 1981. Achieving Wisdom: Knowledge and Politics on Tanna, Vanuatu, $\mathrm{PhD}$ thesis, University of California at Berkeley.

-, 1997. Chiefs In Vanuatu Today, in Geoffrey M. White and Lamont Lindstrom (eds), Chiefs Today: Traditional Pacific Leadership and the Postcolonial State, Stanford, Stanford University Press, pp. 211-228.

Macclancy Jeremy, 1980. To Kill a Bird with Two Stones, Port Vila, Vanuatu Cultural Centre Publications.

Mecartney Sarah Anne Nautong, 2000. Blacksands Settlement: A Case for Urban Permanence in Vanuatu, MS thesis, Department of Geosciences, University of Sydney.

Mitchell Jean, 2000. Violence as Continuity: Violence as Rupture, Narratives from an Urban Settlement Vanuatu, in Sinclair Dinnen and Allison Ley (eds), Reflections on Violence in Melanesia, Canberra, Hawkins Press and Asia Pacific Press, pp. 189-208.

—, 2003. "Killing Time" in a Postcolonial Town: Young People and Settlements in Port Vila, Vanuatu, in Victoria Lockwood (ed.), Pacific Island Societies in a Global World, Inglewood Cliffs, NJ, Prentice-Hall, pp. 358-376.

—, 2011. 'Operation Restore Public Hope': Youth and the Magic of Modernity in Vanuatu, Oceania 81, pp. 36-50,
Pacific Economic Cooperation Council, nd. Port Vila, Vanuatu, www.pecc.org/community/papers/SCTFReports/Noumea/portvila.pdf.

Rawlings Greg, 1999. Foundations of Urbanisation: Port Vila Town and Pango Village, Vanuatu, Oceania 70, pp. 72-86.

Rio Knut, 2010. Handling Sorcery in a State System of Law: Magic, Violence and Kastom in Vanuatu, Oceania 80, pp. 182-197.

-, 2011. Policing The Holy Nation: The State and Righteous Violence in Vanuatu, Oceania 81, pp. 51-71.

Rodman Margaret, Daniela Kraemer, Lissant Bolton and Jean TARISESEI, 2007. HouseGirls Remember: Domestic Workers in Vanua$t u$, Honolulu, University of Hawaii Press.

SHerkin Samantha G., 1999. Forever United: Identity-Construction across the Rural-Urban Divide, PhD thesis, University of Adelaide.

SimÉoni Patricia, 2009. Atlas du Vanouatou (Vanuatu), Port Vila, Éditions Géo-consulte.

Small Cathy A., 1997. Voyages: From Tongan Villages to American Suburbs, Ithaca, Cornell University Press.

Vanuatu National Statistics Office, 2009. National Census of Population and Housing, Port Vila, Ministry of Finance and Economic Management.

Weiss Brad, 2009. Street Dreams and Hip Hop Barbershops: Global Fantasy in Urban Tanzania, Bloomington, Indiana University Press. 